\title{
Developing Teamwork Training Impact Scale: Constructing an Instrument to Determine the Impact of Training on Teamwork Effectiveness using Malaysian Sample
}

\author{
Siti Fardaniah Abdul Aziz, Ummi Kalsom Zakaria
}

\begin{abstract}
The objective of this paper is to report the development of Teamwork Training Impact Scale (TTIS) because there are limited instruments that can measure the impact of training on teamwork effectiveness. Therefore, eight steps to develop instrument as suggested by previous scholar were followed; in which, the instrument reliability, face validity, content validity, and exploratory factor analysis were analysed. The first version of TTIS comprises of 60 items; however, only 24 items left in the final version. Meanwhile, a pilot study was done among the Malaysian Civil Servant Officers; findings indicated a significant different of training impact on teamwork effectiveness as measured before and after training. This demonstrated that TTIS can be used to measure the impact of training on teamwork effectiveness for employee training.
\end{abstract}

Keywords : Teamwork Training Impact Scale, Malaysia, employee training, training effectiveness, Malaysian Civil Servant Officer, human resource, teamwork

\section{INTRODUCTION}

Employee training is one of human resource development program to equipped employee with the right knowledge, skills and attitude in achieving job performance for most countries around the world [1]. Hence, it is crucial to determine the status of training effectiveness [2]. Interestingly, most of human resource development literature has continually referred to the Kirkpatrick's [3] model to determine training effectiveness among employees. Despite the fact of it is easy to use and simple to understand, the model is criticized by scholars including Alliger and Janak in 1989 [4], Holton in 2005 [5], and Reio et al. in 2017 [6]. Therefore, many scholars have been trying to develop new model of explaining training effectiveness from different angles to improve the way of determining training effectiveness [7].

From many perspectives of interpreting training effectiveness, Aguinis and Kraiger [8] have suggested a model that is quite unique but relevant; the model explains that training should be evaluated by determining its impact on individual, followed by teamwork, organization and finally society. Hence, Aziz et al. have taken the challenge by constructing a new instrument to measure training impact on

Revised Manuscript Received on July 22, 2019

Siti Fardaniah Abdul Aziz, UmmiKalsom Zakaria individual effectiveness named ITIS in 2018 [9] and a new instrument to measure training impact on organizational effectiveness named OTIS in 2016 [10]. Hence, the objective of this paper is to report the development of a new instrument to measure training impact on teamwork effectiveness named Teamwork Training Impact Scale (TTIS).

\section{LITERATURE REVIEW}

Kirkpatrick's [3] model to evaluate training effectiveness explains that training should be evaluated by measuring several levels including trainees' reaction followed learning, behavioral changes and organizational results. The model gains popularity because it is easy to understand and simple to use, however, it is actually difficult to imply [6]. In fact, it has been proven that some of the levels are not significantly correlated [11,12]. Hence, Aguinis and Kraiger's [8] produce an alternative model to explain that training should be evaluated by determining its impact on individual, followed by teamwork, organization and finally society. They also suggest that training will only affect higher level of training effectiveness, such as at organizational level, when it has already affected on lower level of training effectiveness, such as at teamwork level. Interestingly, the measurement of the impact of training on teamwork effectiveness have not been discussed further by previous researchers $[9,10]$.

On the other hand, Kraiger et al. [13] argue that individual learning can be measured based on individual competencies including cognitive (knowledge), skills and affective (attitude). This demonstrated that teamwork effectiveness can also be measured using the impact of training on teamwork knowledge, skills and attitude. As succeeded by Aziz et al. [9], the impact of training on individual effectiveness was measured using individual knowledge, skill and attitude; meanwhile, Aziz et al [10) have measured the impact of training on organizational effectiveness using organizational knowledge, skill and attitude.

When it comes to determining teamwork knowledge, Subramaniam and Youndt [14], argue that innovation is important because it can tell us how knowledgeable teamwork in any organization is. Hence, teamwork innovation is a potential measure to determine teamwork knowledge. In addition, Budijanto 
[15] explains that teamwork performance can tell us how a teamwork in any organization is skilful to achieve its goal. Hence, teamwork performance is a potential measure to determine teamwork skill. Additionally, Weimar [16] explains that teamwork quality can tell us the attitude of teamwork in any organization. Hence, teamwork quality is a potential measure to determine teamwork attitude.

Therefore, research questions arise:

i) Can training have impact on teamwork effectiveness?

ii) How can the impact of training on teamwork effectiveness be measured?

iii) Can previous literature help in constructing new measurement of the impact of training on teamwork effectiveness?

\section{MATERIALS AND METHOD}

The development of Teamwork Training Impact Scale (TTIS) is based on instrument development as suggested by Colton and Covert in 2007 [17]. They suggest eight steps to construct an instrument starting with (I) identifying research question, followed by (II) obtaining feedback from stakeholder, (III) identifying research method, (IV) formulating research question, (V) pre-test items and preliminary draft, (VI) revise instrument based on feedback, (VII) pilot study and revise instrument, and (VIII) administer instrument, analyse, and report result.

Consistent with Colton and Covert suggestions [17], instrument construction for TTIS started with Step I by identifying research question through literature review in previous section. Then, Step II was followed by organizing a focus group meeting to define related indicators conceptually and operationally. Next, Step III was followed by determining appropriate research method as suggested by previous scholars. Further, Step IV was followed by constructing relevant items. Furthermore, Step V was followed by pre-test items among small group sample in another focus group meeting. Next, Step VI was followed by organizing a jury validation to refine items. Then, Step VII was followed by organizing a pilot study to revise items using Exploratory Factor Analysis (EFA). Finally, Step VIII was followed by organizing another pilot study to administer instrument, analyse, and report result.

\section{RESULTS AND DISCUSSION}

\section{STEP II}

A focus group involving the research team members was organized on 30 October 2014 to discuss about appropriate conceptual and operational definition to construct TTIS in Step II. There were six members in the research team with each holding a PhD; two of them were specialized in Human Resource Development, and others were specialized in each Human Resource Management, Psychology of Industrial and Organization, Information System, and Community Development respectively. This can be seen as feedback from stake holder to construct TTIS.

Table 1 presents conceptual definition of Teamwork
Training Impact (TTI); in which, TTI is defined as the effect of training output on teamwork effectiveness that can be measured through the teamwork's knowledge, skill and attitude. Hence, TTIS can comprise of three dimensions including teamwork knowledge, teamwork skill, and teamwork attitude

\begin{tabular}{|c|c|}
\hline Dimensions & Operational Definition \\
\hline $\begin{array}{l}\text { Teamwork } \\
\text { Knowledge }\end{array}$ & $\begin{array}{l}\text { Teamwork knowledge is defined } \\
\text { as teamwork innovation that can } \\
\text { be measured by determining the } \\
\text { ability to identify and use } \\
\text { opportunity to produce new } \\
\text { product, service or work process } \\
\text { through the ability to increase and } \\
\text { create radical innovation. }\end{array}$ \\
\hline $\begin{array}{l}\text { Teamwork } \\
\text { Skill }\end{array}$ & $\begin{array}{l}\text { Teamwork skill is defined as } \\
\text { teamwork performance that can } \\
\text { be measured using the } \\
\text { effectiveness, efficiency, and } \\
\text { meeting standard time to } \\
\text { complete job task. }\end{array}$ \\
\hline $\begin{array}{l}\text { Teamwork } \\
\text { Attitude }\end{array}$ & $\begin{array}{l}\text { Teamwork attitude is defined as } \\
\text { teamwork quality that can be } \\
\text { measured in the quality of } \\
\text { communication, coordination, } \\
\text { effort, mutual support, and united } \\
\text { among team members in } \\
\text { completing task to meet job } \\
\text { performance. }\end{array}$ \\
\hline
\end{tabular}

\section{STEP III}

Quantitative research method was selected to develop TTIS in Step III. In this method, the instrument will be tested using content validity, face validity, EFA, and reliability. This is consistent with suggestion by Hinkin [18], Neuman [19], and Holton [5]. The development of TTIS is consistent with three early steps suggested by Hinkin including organizing item generation, questionnaire administration, and initial item reduction.

Meanwhile, Holton [5] suggests using EFA for initial item reduction in the early phase of instrument development. In addition, Neuman [19] suggests that an instrument should be tested for its reliability and validity; hence, the Cronbach's Alpha reliability and some validity tests were analysed including the face and content validity

\section{STEP IV}

Items in TTIS were developed by adapting items from previous research to construct new measurement of TTIS in Step IV. The first version of TTIS comprises of 60 items to measure teamwork knowledge, teamwork skills, and teamwork attitude.

Ten items were developed to measure teamwork knowledge through teamwork innovation. An instrument of measuring incremental innovation and radical innovation developed by Subramaniam and Youndt [14] that consist of 6 items were adapted; meanwhile, another 4 
items were self-constructed.

Further, teamwork skill was measured through teamwork performance; 15 items were developed. These items were adapted from 6 items measuring teamwork performance developed by Budijanto [15] and 7 items measuring teamwork performance by Weimar [16]; meanwhile, 2 items were self-constructed.

Furthermore, to measure teamwork attitude through teamwork quality, 35 items were developed. These items were adapted from 23 items measuring teamwork quality developed by Budijanto [15] and 39 items measuring teamwork quality by Weimar [16]. In sum, there were 60 items in the early development of TTIS. Items were developed in Bahasa Melayu and English versions. STEP $V$

The early 60 items of TTIS generated in this research was tested among small sample group using purposive sampling in Step V. Respondents consist of 20 postgraduate students specializing in Psychology of Industrial and Organization from UniversitiKebangsaan Malaysia. In this pre-test, respondents were asked to refine these items on a focus group meeting on 18 to 19 March 2015. During these focus group discussions, the face validity was verified; in which, items were refined. Sample question for teamwork knowledge was "My team produce innovations that reinforce how we are currently competing". Sample question for teamwork skill was "Project goals are met by my team". Sample question for teamwork attitude was "The team members helped and supported each other as best they could".

\section{STEP VI}

The TTIS was revised again in jury validation involving twelve juries to verify content validity in Step VI. Three juries were the subject matter experts that hold $\mathrm{PhD}$ in Human Resource Management and Development from Universiti Putra Malaysia (UPM) and UniversitiTeknologi MARA (UITM), Malaysia. Another five juries were practitioners that hold management positions in Malaysian government agencies including UPM, UITM, Civil Service Department, and Malaysian Islamic Preaching Foundation. Meanwhile, another four juries were postgraduate students specializing in Human Resource Development at UPM that hold management positions in Malaysian organization. These juries were given conceptual and operational definition to give marks and suggestion to improve TTIS; these juries have also consented to participate in the research. The twelve juries were asked to rate their agreeableness for each item using scale 1 to 10 ; scale 1 represents "strongly disagreed" and 10 represents "strongly agreed". The total averages were then divided into 10 to create level of reliability. According to Hair et al. [X], the level of reliability that can be accepted is more than 0.7 ; however, “...it may decrease to 0.6 in exploratory research" (p.137). Hence, items that have the average score percentage more than 0.6 were included in the next stage of ITIS development; all the 60 items remained at this stage. The average score percentage for each construct were higher than 0.8 ; this is shown in Table 2.
Table 2: Results for jury validation to verify content validity in TTIS

\begin{tabular}{lclcc} 
Components & $\begin{array}{c}\text { Numbe } \\
\mathbf{r} \text { of } \\
\text { items }\end{array}$ & $\begin{array}{c}\text { Type of } \\
\text { Juries }\end{array}$ & $\begin{array}{c}\text { Average } \\
\text { Score } \\
\text { Percentag } \\
\text { e }\end{array}$ & $\begin{array}{c}\text { Total } \\
\text { Average } \\
\text { Percentage }\end{array}$ \\
\hline Teamwork & 10 & SME & 0.84 & \\
Knowledge & & Practitioner & 0.81 & \\
Teamwork Skill & 15 & SME & 0.78 & 0.81 \\
\hline Teamwork & & Practitioner & 0.86 & \\
Attitude & 35 & PS & 0.79 & 0.83 \\
\hline & & SME & 0.85 & \\
& & Practitioner & 0.83 & \\
\hline
\end{tabular}

Notes: SME = Subject Matter Expert; PS=Postgraduate Student

\section{STEP VII}

First pilot study was organized among Government's Civil Servants in Malaysia using purposive sampling in Step VII to reduce items in EFA. Samples were taken among government staff that work at the same organization with postgraduate students registered with the subject of Training Evaluation (DCE5232) at Universiti Putra Malaysia during November to December 2015. Purposive sampling was used because the objective of this study was to develop an instrument and not to make generalization for a population. A total number of 450 respondents were involved; however, respondents working at government agencies at Putrajaya were excluded because those respondents will be included in the second pilot study. Data were analysed using EFA.

The EFA analysis was forced into three factors in TTIS to determine appropriate items for each dimension of TTI including teamwork knowledge, teamwork skills and teamwork attitude. Table 3 presents the EFA result; only 24 items left in this analysis. Items that had factor loading less than 0.5 were omitted. The Kaiser-Meyer-Oklin value was 0.943 and the Bartlett's Test of Sphericity was significant ( $p$ $=0.0001$ ), which is consistent with the value recommended by Pallant [20]. Meanwhile, the Maximum likelihood analysis revealed the presence of three components with eigenvalues exceeding 3 , explaining $53.022 \%, 12.55 \%$, and $7.39 \%$ of the variance respectively. In addition, the oblimin rotation was performed and the pattern matrix indicated that each item shows strong loading in only one component. Additionally, the correlation matrix indicated that most items have positive correlation with 0.4 and above. At this stage, only 24 items remained in TTIS; in which, there were 6 items measuring teamwork knowledge, 8 items measuring teamwork skill, and 10 items measuring teamwork attitude. 
Developing Teamwork Training Impact Scale: Constructing an Instrument to Determine the Impact of Training on Teamwork Effectiveness using Malaysian Sample

Table 3: Results for Exploratory Factor Analysis (EFA)

\begin{tabular}{|c|c|c|}
\hline Num. & $\begin{array}{c}\text { Items for Factor } \\
\text { Loading }\end{array}$ & Factor Loading \\
\hline \multicolumn{3}{|c|}{ Teamwork Knowledge } \\
\hline 1. & KPA6 & .909 \\
\hline 2. & KPA8 & .894 \\
\hline 3. & KPA7 & .827 \\
\hline 4. & KPA10 & .809 \\
\hline 5. & KPA9 & .757 \\
\hline 6. & KPA5 & .756 \\
\hline \multicolumn{3}{|c|}{ Teamwork Skill } \\
\hline 1. & KSA33 & .941 \\
\hline 2. & KSA31 & .897 \\
\hline 3. & KSA34 & .865 \\
\hline 4. & KSA32 & .847 \\
\hline 5. & KSA35 & .841 \\
\hline 6. & KSA30 & .780 \\
\hline 7. & KSA29 & .773 \\
\hline 8. & KSA28 & .751 \\
\hline \multicolumn{3}{|c|}{ Teamwork Attitude } \\
\hline 1. & KKA10 & .931 \\
\hline 2. & KKA12 & .870 \\
\hline 3. & KKA6 & .861 \\
\hline 4. & KKA9 & .849 \\
\hline 5. & KKA14 & .835 \\
\hline 6. & KKA13 & .827 \\
\hline 7. & KKA7 & .826 \\
\hline 8. & KKA8 & .805 \\
\hline 9. & KKA15 & .801 \\
\hline 10. & KKA11 & .770 \\
\hline $\begin{array}{l}\text { Notes: } \\
\mathrm{KKA}=\mathrm{Te}\end{array}$ & $\begin{array}{l}\text { KPA=Teamwork } \\
\text { amwork Attitude }\end{array}$ & KSA=Teamwork \\
\hline
\end{tabular}

\section{STEP VIII}

Second pilot study was organized in Step VIII among Government Civil Servant officers at multiple government agencies at Putrajaya, Malaysia that attended training organized by the Public Administration Institute of Malaysia (INTAN) in 2015. The objective of second pilot test is to determine reliability of TTIS as well as to determine whether TTIS can be used to determine the impact of training on teamwork. A total number of 221 respondents were involved; however, only 211 respondents were selected due to outliers. Respondents have to answer the questionnaire based on 5 Likert scale; they also have to remember their perception before and after the most preferred training organized by INTAN that they have attended previously. INTAN provides training programs for the Civil Servant Officers.

Using TTIS, the Cronbach Alpha reliability tests have shown a high value for each teamwork knowledge (Cronbach Alpha $=.938)$, teamwork skill (Cronbach Alpha $=.955)$, and teamwork attitude (Cronbach Alpha $=.964)$. For overall, the reliability for TTIS is Cronbach Alpha $=.963$. This has shown that TTIS is a reliable instrument.
Further, a correlation test was organized using Pearson correlation between teamwork knowledge, teamwork skill, and teamwork attitude using the mean score for their perception after training completion. Findings indicated significant relationship; this is presented in Table 4. This indicated that TTI comprise of teamwork knowledge, skill and attitude, and can be measured using TTIS. These competencies have a significant relationship and can be used to determine the impact of training on teamwork effectiveness.

Table 4: Correlation between dimensions in TTI

\begin{tabular}{|c|c|c|c|c|}
\hline \multirow[t]{3}{*}{ Dimensions } & \multicolumn{3}{|c|}{ Correlations } & \\
\hline & Teamwork & Teamwork & Teamwork & \\
\hline & Knowledge & Skill & Attitude & \\
\hline \multirow{5}{*}{$\begin{array}{l}\text { Teamwork } \\
\text { Knowledge }\end{array}$} & Pearson & 1 & $.547 * *$ & $.640^{*}$ \\
\hline & Correlation & & & \\
\hline & Sig. & & .000 & .000 \\
\hline & (2-tailed) & & & \\
\hline & $\mathrm{N}$ & 211 & 211 & 211 \\
\hline \multirow{5}{*}{$\begin{array}{l}\text { Teamwork } \\
\text { Skill }\end{array}$} & Pearson & $.547 * *$ & 1 & $.470^{*}$ \\
\hline & Correlation & & & \\
\hline & Sig. & .000 & & .000 \\
\hline & (2-tailed) & & & \\
\hline & $\mathrm{N}$ & 211 & 211 & 211 \\
\hline \multirow{4}{*}{$\begin{array}{l}\text { Teamwork } \\
\text { Attitude }\end{array}$} & Pearson & $.640 * *$ & $.470^{* *}$ & 1 \\
\hline & Correlation & & & \\
\hline & Sig. & .000 & .000 & \\
\hline & $\mathrm{N}$ & 211 & 211 & 211 \\
\hline
\end{tabular}

Notes: **significant at 0.01 level

Furthermore, a paired sample t-test was used to determine the impact of training on teamwork effectiveness using TTIS. The mean score for before and after training were tested using paired sample t-test; the results are presented in Table 5. Findings indicated significant difference in the scores for after $(\mathrm{M}=4.20, \mathrm{SD}=.54)$ and before $(\mathrm{M}=3.25, \mathrm{SD}=.86)$ training completion for teamwork knowledge [ $\mathrm{t}(210)=$ 16.18]; after $(\mathrm{M}=4.30, \mathrm{SD}=.50)$ and before $(\mathrm{M}=3.37, \mathrm{SD}$ $=.78)$ training completion for teamwork skill [t $(210)=$ 17.33]; and that after $(\mathrm{M}=4.31, \mathrm{SD}=.51)$ and before $(\mathrm{M}=$ $3.34, \mathrm{SD}=.74)$ training completion for teamwork attitude [ $\mathrm{t}$ $(210)=18.99]$.

The magnitude of the differences in the mean score for each teamwork knowledge (eta squared $=.5549)$, teamwork skill (eta squared $=.6003$ ), and teamwork attitude (eta squared $=$ .6321) was large. In fact, the paired samples correlations shows a significant correlation between the mean score for before and after for each teamwork knowledge $(\mathrm{r}=.351, \mathrm{p}=$ $.01)$, teamwork skill $(\mathrm{r}=.336, \mathrm{p}=.01)$, and teamwork attitude $(\mathrm{r}=.338, \mathrm{p}=.01)$. The paired sample t-test has demonstrated that there is significant increase of teamwork competencies as measured before and after training completion; these imply that the impact of training on teamwork effectiveness can be measured using TTIS. 
Table 5: Correlation between dimensions in TTIS

\begin{tabular}{|c|c|c|c|c|c|c|c|c|c|}
\hline & \multicolumn{3}{|c|}{ Paired Differences } & & & & & & \\
\hline & \multirow[t]{2}{*}{ Mean } & \multirow[t]{2}{*}{$\begin{array}{l}\text { Std. } \\
\text { Deviation }\end{array}$} & \multirow[t]{2}{*}{$\begin{array}{l}\text { Std. } \\
\text { Error } \\
\text { Mean }\end{array}$} & \multicolumn{2}{|c|}{$\begin{array}{l}95 \% \text { Confidence } \\
\text { Interval of the } \\
\text { Difference }\end{array}$} & \multirow[t]{2}{*}{$\mathrm{t}$} & \multirow[t]{2}{*}{ df } & \multirow[t]{2}{*}{$\begin{array}{l}\text { Sig. (2- } \\
\text { tailed) }\end{array}$} & \multirow[t]{2}{*}{$\begin{array}{l}\text { Eta } \\
\text { Squared }\end{array}$} \\
\hline & & & & Lower & Upper & & & & \\
\hline $\begin{array}{l}\text { Pair 1: } \\
\text { Teamwork } \\
\text { Knowledge } \\
\text { After- Before }\end{array}$ & .95456 & .85679 & .05898 & .83829 & 1.07084 & 16.183 & 210 & .000 & 0.5549 \\
\hline $\begin{array}{l}\text { Pair 2: } \\
\text { Teamwork Skill } \\
\text { After- Before }\end{array}$ & 92386 & .77423 & .05330 & .81879 & 1.02894 & 17.333 & 210 & .000 & 0.6003 \\
\hline $\begin{array}{l}\text { Pair 3: } \\
\text { Teamwork Skill } \\
\text { After- Before }\end{array}$ & 96751 & .73975 & .05093 & .86712 & 1.06790 & 18.998 & 210 & .000 & 0.6321 \\
\hline
\end{tabular}

\section{CONCLUSION}

The purpose of this study was to report the construction of new instrument to measure the impact of training on teamwork effectiveness named Teamwork Training Impact Scale (TTIS). Eight steps to develop instrument as suggested by Colton and Covert in 2007 were followed. Finding indicated that TTIS passed all the eight steps and was validated for face validity, content validity, reliability, and EFA. The first version of TTIS comprises of 60 items, however, only 24 items left in the final version. In fact, findings indicated that there is a significant impact of training provided by INTAN on teamwork effectiveness among the Malaysian Civil Servants Officers; this implies that TTIS can be used to determine the impact of training on teamwork effectiveness. In addition, future research is suggested to verify TTIS using other types of validity including construct and concurrent validity by using other samples especially organisation with business oriented. Therefore it is recommended for human resource development practitioners and researchers to use TTIS for the purpose of determining the impact of training on teamwork effectiveness.

\section{ACKNOWLEDGMENTS}

Special thanks to the Ministry of Education Malaysia and UniversitiKebangsaan Malaysia (UKM) that supported the research under Prototype Research Grant (PRGS/1/2017/SS03/UKM/02/1) and Fundamental Research Grant (FRGS/1/2014/SS02/UKM/ 02/3). Teamwork Training Impact Scale (TTIS) has been registered for intellectual property Copyright at UKM.

\section{REFERENCES}

1. Garavan, T. N., McCarthy, A. M., \& Morley, M. J., ed. "Global Human Resource Development: Regional and Country Perspectives". Edited by Garavan, T. N., McCarthy, A. M., \&
Morley, M. J., Global Human Resource Development: Landscaping the Anatomy of an Evolving Field. New York: Routledge, 2016.

2. Noe, R.A. Employee Training and Development. 7 ed. Boston: McGraw Hill, 2017.

3. Kirkpatrick, D. "Great Ideas Revisited: Revisiting Kirkpatrick's Four-Level Model." Training and Development vol.50, 1996, pp.54-7.

4. Alliger, G. M., \&Janak, E. A. "Kirkpatrick's Level of Training Criteria: Thirty Years Later." Personnel Psychology vol.42, 1989, pp.331-42.

5. Holton, E. F., III. "Holton's Evaluation Model: New Evidence and Construct Elaborations." Advances in Developing Human Resources vol.7, no.37, 2005, pp. 37-54.

6. Reio, T. G., Rocco, T. S., Smith, D. H., \& Chang, E. "A Critique of Kirkpatrick's Evaluation Model." New Horizons in Adult Education and Human Resource Development vol.29, no.2, 2017, pp. 35-53.

7. Aziz, S. F. A. KeberkesananLatihan Dan Pembangunan SumberManusia. Bangi, Selangor, Malaysia: Penerbit UKM, 2018.

8. Aguinis, H., \&Kraiger, K. "Benefits of Training and Development for Individuals, and Teams, Organizations, and Society." Annual Review of Psychology vol.60, 2009, pp.451-74.

9. Aziz, S. F. A., Silong, A. D., \& Zakaria, Z. "Developing Individual Training Impact Scale for Workplace Training: Testing the Malaysian Sample to Determine the Impact of Training on Individual Effectiveness." Advanced Science Letters, 2018, vol.24, pp.5067-69.

10. Aziz, S. F. A., Silong, A. D., Ahmad, K., Selamat, M. N., Roslan, M. R. H., \& Manan. M. R. A. "Developing Organizational Training Impact Scale for Workplace Training: Testing the Malaysian Sample to Determine the Impact of Training on Organizational Effectiveness." International Journal of Economics and Financial Issues vol.6, no.S6, 2016, pp.142-48.

11. Alliger, G. M., Tannenbaum, S. L., Bennett, W. Jr., Traver, H., \& Shetland, A. "A Meta-Analysis of the Relations among Training Criteria." Personnel Psychology vol.50, 1997, pp.341-58.

12. Arthur Jr, W., Bennett Jr, W., Edens, P. S., \& Bell, S. T. "Effectiveness of Training in Organizations: A Meta-Analysis of Design and Evaluation Features." Journal of Applied Psychology vol.88, no. 2, 2003, pp.234-45.

13. Kraiger, K., Ford, J. K., \& Salas, E. "Application of Cognitive, Skill-Based, and Affective Theories of Learning Outcomes to New Methods of Training Evaluation". Journal of Applied Psychology vol.78, 1993, pp.311-328.

14. Subramaniam, M., \&Youndt, M. A. "The Influence of Intellectual Capital on the Types of Innovative Capabilities." Academy of Management Journal 48, no. 2 (2005): 450-63.

15. Budijanto, R. R. "Thinking Styles, Teamwork Quality and Performance". Unpublished doctoral dissertation, University of Canberra, Canberra, Australia, 2013.

16. Weimar, E. "The influence of teamwork quality on software team performance". Unpublished masters dissertation, Tilburg University, Tilburg, Netherlands, 2013.

17. Colton, D., \& Covert, R. W. Designing and Constructing Instruments for Social Research and 
Evaluation. San Francisco: John Wiley \& Sons, 2007

18. Hinkin, T. R. "A Brief Tutorial on the Development of Measures for Use in Survey Questionnaires." Organizational Research Methods vol.1, no. 1, 1998, pp.104-21.

19. Neuman, W.L. Social Research Methods: Qualitative and Quantitative Approaches. 7 ed. Massachusetts: Allyn and Bacon, 2010.

20. Pallant,T Julie.T SPSST SurvivalT Manual.T 4T ed.T Australia:T AllenT $\& \mathrm{~T}$ Unwin, $\mathrm{T} 2011$

\section{AUTHORS’ PROFILE}

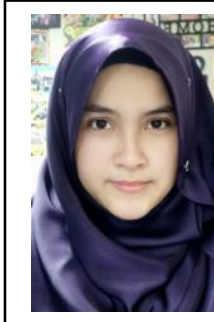

Siti Fardaniah Abdul Aziz is a Senior Lecturer at UniversitiKebangsaan Malaysia /UKM (National University of Malaysia). She is now holding leadership positions as Head of Research Cluster and Intellectual Property Ambassador at Faculty of Social Sciences \& Humanities, UKM. She had her PhD., MSc., and BSc. in Human Resource Development field of study and have been involved as academics for more than 15 years. She was awarded for Outstanding Women in Management Award (2017) by Venus International Foundation, an international body of NGO. She had also received Excellent Service Award by UKM in 2015 and Outstanding Research Student Award by UPM in 2013. She has written more than 50 publications including books, magazine article, learning module, and journal articles indexed in ISI Q1, SCOPUS, ERA and other high indexed journals. She had also registered more than 10 copyrights of intellectual property including learning modules, instruments, and computer system related to Human Resource Development field of study. She had also lead more than 5 research grants within 5 years. She is also active in teaching, supervision, social services, academic writing, training, and research.

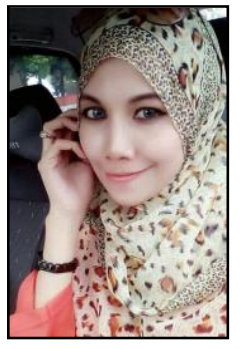

Ummi Kalsom Zakaria received her BSc. and MSc. in Human Resource Management (HRM) field of study from Univeristi Utara Malaysia /UUM (North University of Malaysia). She is now a PhD. candidate at UniversitiKebangsaan Malaysia /UKM (National University of Malaysia). She is currently working as Human Resource Manager at USA Passion Development Sdn. Bhd. She has more than 10 years' experience as Human Resource Manager at various organizations in Malaysia. She has vast experience as HRM Manager and Trainer especially in managing and developing human resources including career management and development, training and coaching, talent management, compensation management, performance appraisal, organization development and change, human resource planning, job design, selection and staffing, industrial relation, etc. 